UDC 316.773.3-024

https://doi.org/10.23939/sjs2019.01.136

Paraskoviia Dvorianyn

$\mathrm{PhD}$, associated professor,

Department of Journalism and mass communication,

Lviv Polytechnic National University,

paraska@radiolux.com

\title{
STRUCTURE OF NEWS MESSAGES \\ AS A TOOL OF COMMUNICATION
}

(C) Dvorianyn Paraskoviia, 2019

Thearticleoutlinesthestructureofnewsreports, describesthewaysofnewspublishing, which has been developed by journalist practice. Since mass media should not chaotically translate information that is in demand, but rather should predict the impact this information has on society, the features of hard and soft news are compared in our study.

Now it is necessary to overcome stereotypes that correspondent just informs, because it leads to the simplification of the media. These stereotypes move into the consciousness of a new generation of journalists. Regional media usually offer the same topics, similar actors. The communication system remains unchanged and predictable. Scholars who are quoted in the study suggest properly going beyond the usual and looking for feedback, which will make it possible to differentiate from others.

In order to achieve effective communication with the audience, in this article we offer journalists a deeper understanding of the answers during the preparation of news reports. Since news is the current information about facts, events, phenomena of social significance, it has to correspond to certain requirements. Facts become meaningful when placed in a structure or plot line that arranges them, choosing one and ignoring others. Releases on regional TV channels do not often correspond to the developed and formulated standards.

In the given research we have outlined, comprehended method of preparation of a news message. Based on the results of scientific reflection on the theory of television communication and analysis of news content, the optimal structure of news reports has been recommended. The basic segments of this structure are absolute, national, civic, family, personal values and socio-humanistic needs of viewers.

Key words: news; TV; identity; values; audience; recipient; content; correspondent; fact; message.

Парасковія Дворянин

канд. наук із соц. ком., доц. кафедри ЖЗМК,

Національний університет

“Львівська політехніка"

\section{СТРУКТУРА НОВИННИХ ПОВІДОМЛЕНЬ ЯК ІНСТРУМЕНТ КОМУНІКАЦІЇ}

Окреслено структуру новинних повідомлень, описано способи оприлюднення новин, які виробила журналістська практика. Оскільки засоби масової комунікації не можуть хаотично подавати ту інформацію, на яку с попит, а повинні передбачати вплив 
цієї інформації на суспільство, у нашому дослідженні порівняємо особливості жорстких (важких) і м'яких (легких) новин.

Тепер потрібно подолати стереотипи, якими послуговується журналіст, адже це призводить до спрощення засобів масової інформації. Регіональні ЗМІ зазвичай пропонують ті самі теми, аналогічних дійових осіб. Система комунікації залишається незмінною i передбачуваною. Науковці, яких цитуємо в дослідженні, пропонують належно виходити за межі звичного і шукати зворотний зв'язок, що дасть можливість диференціювати їх від інших.

Для досягнення ефективної комунікації з аудиторісю у цій статті пропонуємо журналістам глибше розуміння відповідей на запитання під час підготовки новинних повідомлень. Оскільки новина є актуальною інформацісю про факти, події, явища соціальної значущості, вона повинна відповідати певним вимогам. Факти набувають значення, коли їх поміщають у структуру або сюжетну лінію, що упорядковус їх, вибираючи один та ігноруючи інші. Новинні повідомлення на регіональних телеканалах не завжди, точніше часто, не відповідають виробленим і сформульованим стандартам.

У дослідженні окреслено, осмислено метод підготовки новинного повідомлення. За результатами наукового осмислення теорії телевізійної комунікації та аналізу новинного контенту рекомендовано оптимальну структуру новинних повідомлень. Основними сегментами цієї структури є абсолютні, національні, громадянські, сімейні, особисті цінності й розроблена нами структура соціогуманістичних потреб телеглядачів.

Ключові слова: новини; телебачення; ідентичність; цінності; аудиторія; реципієнт; контент; кореспондент; факт; повідомлення; випуск.

The general problem, its scientific and practical value. Informational space of Ukraine is filled with various news messages. They generate certain opinions in the public consciousness. Nowadays the person in need of information has a wide range of possibilities for search of news. Internet agencies, social networks, blogs, etc. allow the user to become a part of the community and influence the content. There is the undeniable opportunity to be the creator of the most diverse news.

The communication chain "fact $\rightarrow$ news $\rightarrow$ TV channel-interest / the need of a person $\rightarrow$ personal and social reaction" creates a new fragment that changes the usual reality, so considerable attention should be paid to the content of the news. Consequently, the preparation of a news message is one of the most important stages in the informational activity of a TV journalist. The author should adhere to a number of requirements, the implementation of which ensures the communicative effectiveness of news.

Being a direct participant in the communicative process, the television journalist uses certain ways to construct and submit a news message. The news message must be constructed in a way that makes it easier to perceive the information contained therein.

Analysis of researches, publications.Among the requirements, which are often mentioned in public speeches and in scientific research, - it is necessary to separate information from the journalist's biased opinion. Jonathan Hoffman, Worldwide Project Manager for the Syndicate, notes that "today the role of journalism is to give the news some meaning" [12]. Such an understanding of the essence of news denies the "simplified model" that is proposed by worldwide services of television and radio companies [6, p. 8].

L. Vasilieva quotes E. Dennis and Dzh. Merrilla: "news is a message that outlines a modern view of reality on a particular issue, event or process. The news can indicate important changes for the individual or society that are presented in the context of a generally accepted or typical "[4, p. 240]".

E. Dennis and J. Merrill emphasize that the news is drawn up in accordance with the consensus of interests of the audience and the constraints of every media (ethical, ideological, etc.).

In particular, the journalist and editorial staff are often assigned the role of a sorter who not only selects, but also creates a separate piece of news, introducing it into the general context of the events of the 
day. This process can be compared with the game, but it is not accidental, the game should be played under certain rules [16].

As O. Vasina observes, taking into account that the basis of TV news information, as well as all journalism, is the facts, "the fact that changes the situation, acts as a universal and mandatory component of any news message" [7, p. 142].

Opinion on the essence of news that is expressed by J. Bryant is worth mentioning: "News is a process that has begun in the recent past, exists in the present and will continue in the future. So the background to the news and its context are important to the same extent as the following messages. You can also say that the news by nature is unstable and variable ... News as useful social knowledge consists of many elements " $[2$, p. 258].

A news message in any mass media is "a new information", more precisely "a message about a certain actual event that is of public interest, or even more narrowly understood - a certain journalistic genre based on established rules (verbal, graphic or television news). [14, p. 502], - notes Winfried Schultz.

A journalist, informing and surprising the audience, should also care about the fact that his materials should not be lost in the information flow. "The mission of a journalist is primarily to inform society, to provide enough information for viewers to understand the world in which they live, especially when the viewer is the object of gross manipulations. Although classic interpretation of the news as a short message that answers the question-what? where? When? with whom? Why? and how did it happen? is universal, but in order to carry out the mission mentioned above, the journalist have to be still exclusively responsible" [5, p. 40].

Professor Serhiy Demchenko is convinced that the situation of monotony in the news is caused by a lack of proper qualifications, the fear of going beyond the usual, well-known communication field $[3$, p. 300].

The purpose of the study is to analyze the structure of the news message, to distinguish its features and components; to indicate, whether with the development of modern media, the structure of the news message is changing and improving for the sake of understanding between journalists and audience; to offer the concept of creating news messages.

Presentation of the material.After analysis of different opinions of researchers and own journalistic practice of the author, I believe that the news message is selected, organized and embodied in a certain form information about facts, events, phenomena that is specially designed to be perceived by feelings and conscience. Professor Y. Prokhorov identifies at least three requirements for the structure of news [10, p. 19-20]. The first requirement is that the news should contain original and unique information. Uniqueness in this case means a novelty of information, the presence in the messages of new knowledge, ideas, values, which the viewer does not yet know. The news that is meant to restore in memory the facts, events, ideas that "have gone" to the periphery of consciousness are also considered to be original. The news that prompts us to use actively the previously obtained information for a better understanding of the problems is also unique. The second requirement is that the news should be accessible and understandable. It should not cause difficulties during the perception. Violation of this requirement leads not only to a misunderstanding of the message, but also to cognitive and informational losses. The third requirement is that the news should contain valuable information that meets the concerns and interests of the audience. The motivation for drawing the public attention to news reports is its subjective interests. Knowledge of the interests of the audience and the ability to make objectively necessary information subjectively important is an essential condition for the effective impact of news on the recipient.

Failure to comply with at least one of these requirements deprives the news of the required informational saturation and restricts the spectrum of viewers' expectations.

The theory and practice of journalism has developed a number of ways to publish news reports. Professor O. Meleshchenko noted that before the civil war in the United States, American journalists built 
the content and composition of their messages (mostly breaking news) on the principle of a direct pyramid, in which the central essence of the news was taken at the end of the journalistic text [8, p. 19].

However, during the civil war between representatives of the North and South of the United States, an event that radically changed the journalistic approach to the creation of a news narrative had taken place. This is a long-standing story about the interruption of telegraph communication, that led to the unknown to the Americans and the world outcome of the battle of two armies near the city of Gettysburg. When the connection resumed, American journalists began to describe the battlefield, the ammunition of the soldiers, the color of the uniforms, and other details according to the professional standards before moving directly to the main event. They did not know that the connection worked for a short time, and in the middle of the program their text was lost again. The Americans and the world did not know again about the winner of the battle under the city of Gettysburg. Since then journalists of mass media began to build a composition of their messages based on the new principle of the inverse (inverted) pyramid. The principle of the inverted pyramid implies that the most important information - the main message - is at the beginning of the text. Further, due to the principle of remoteness, less important information is placed. The most important information is located in the first paragraph - preamble. The next is the core of what it is all about. Then less important, but quite interesting details and moments. Within the "inverted pyramid," the journalist should answer six main questions: WHO, WHO, WHERE, WHEN, HOW, IN WHAT WAY.

In such materials, the statement is consistent. Journalists, even if they use an emotional component, then immediately decipher and explain it. In the PR industry, this form of presentation of the material is also called anticlimax. Such a construction of TV news does not hold in the tension and does not make them wait for answers to the questions. Instead they appear in the plot immediately.

There is also a structural model for building a news television message in the "rectangle" scheme. This method is predominantly used in the preparation of other than breaking news.The event, details and main component of the message are distributed among the explanatory material.

If all material and its components are equivalent in importance, journalists use the principle of a rectangle. As for the inverse and direct pyramid, and for the rectangle, the division into the main blocks is important: the introduction (sometimes it is called "a showcase"), the main part (body), the ending. The introduction is extremely important because it determines whether the viewer perceives the material in general. Journalists often prepare an introduction that informs the audience about an event, and in the main part (the corpus), this information logically proceeds - from the most important facts to the less important. There is also an introduction that summarizes the causes and outcome of the event, and then chronologically reveals the content of what happened.

The news also uses the model of the "sand clock" to actually leak together the inverse and straight pyramid. "Such a model of a news message introduced in the scientific circle the term "prelude", which prepares the viewer / listener to directly perceive the lead", notes O. Meleshchenko [8, p. 21].

However, the technology of "sand watch" for news preparation has not yet been widely used on the regional TV channels that we are exploring. The model of the so-called "diamond" [15, p. 229], which in the western media has already become a standard, has not become popular now. This model assumes: the problem or subject of information is introduced at the beginning of the material through a specific example; add comments of the experts, as well as the other information explaining the problem (this part is the main and largest in the timekeeper; the message ends with a return to a person or group of people, an example of which was used in the plot [9, p. 52].

Scholar M. Nedopytanskyy admits that the "diamond" model does not override the well-known model of the "inverse pyramid" (when the foreground of the news message indicates the most important fact, and then the facts are laid down in order of decreasing their importance).

Justification of the results. The method of creating a news message involves satisfying "human interest", which also means the interest of each individual in the lives of other people. "The main and only subject of television is a human. On television, everything is perceived only through human", - says V. Sappak [13, p. 152, 153]. 
The highly professional preparation of news is determined by a deep understanding of the concept of American scholar A. Maslow. Psychological characteristics of self-actualizing person should be the basis of the news message. These are developed creative abilities; active perception of reality and the ability to navigate well in it; spontaneity in actions and spontaneity in expressing their thoughts and feelings; the ability to accept oneself and other people as they are; the ability to have a profound understanding of life; presence of a sense of humor; settlement with people around, though not with all, benevolent personal relationships; the ability to look at life with open eyes, to evaluate it objectively, impartially [1, p. 37].

As a result of the division of the media to entertaining and opinion-making, the separation of news into "hard" and "soft" ones was distinguished. The time of the publication of "hard" news is the date of the event itself, which can be predefined (for example, when it comes to the planned legislative initiative) or the unexpected (fire). A "hard" news is a message concerning events involving key leaders, meaningful issues or facts that go beyond the ordinary. Such news is traditionally considered important for a wellinformed and interested society. In hard news, the viewer finds answers to the questions "What?", "Who?", "Where?", "When?".

Consequently, hard news is characterized as short, serious and meaningful. They, as far as possible, inform objectively and in an impersonal style. "Soft" news is not connected with public affairs, they are rather more personal, bright and spectacular, less tied to time, more dramatic. They are characterized mainly by the personal presentation of the material and by less official language of presentation. Sometimes this news has time bindings, its softness actually is determined by the form of presentation.

As you can see, soft news may not be structured due to the importance of information, but they give an attractive detail that indirectly answers one of the four questions "What?", "Who?", "Where?", "When?" in the beginning. Until the end, they hold the "zest" -intimate information, quotation, trick. News of this type include accidents and crimes, corruption and personal affairs, sports, social events etc. Kurt Reumann enlisted such topics as follows: blood, beauties, teams, love, babies [11, p. 246]. If the news is presented with entertainment purposes, then this is denoted by the English term "infotainment", that is, the combination of entertainment and information components. The experts of NGO "Telekrytyka" singled out the following features of infotainment techniques on Ukrainian channels: news play; the use of infographics and animation; using excerpts from movies, music (to create an appropriate emotional mood); emphasis on unimportant but vivid details; intonation. However, during the analysis of TV materials, we found not so many examples of infotainment. On this basis, we believe that this new format still remains unfulfilled during the news preparation. However, we find examples of non-standard thinking, and this, in our opinion, is the basis of infotainment.

The preparation of soft news does not let the authors (the journalist and the cameraman first of all) produce the news that lack the reliability, truthfulness, morality of information. After all, the news message is a means of forming the individual and civic, national consciousness, political influence, intellectual and spiritual enrichment of viewers.

Based on the methodology of displaying and the results of the survey of reporters of regional TV channels ( 75 people), we can assert that during the creation of a news message, one has to adhere to the following methodological requirements: be able to correctly isolate a social fact without isolating it from the social environment, which is determined by the unity of the general, special and unitary; do not violate the organic authenticity of the fact of the selection of certain (substantial or non-essential) ties; consider the fact from the point of view of the general laws that determine the phenomenon as such; do not forget about the heredity of the facts displayed on the television screen, which allows us to somehow synthesize our knowledge of reality; actively reflect the regional reality in the context of all-Ukrainian and general human socio-humanistic interests. In order for the news to be made public through the media, in particular regional TV channels, it should be fresh, previously unknown, close to the audience, unusual, personified, important, spiritually and mentally inspired.

Conclusions. The analysis of news releases of regional TV channels, interviews with viewers shows that the communicative effectiveness of news can be achieved in compliance with methodological requirements, the essence of which is that the news should contain original information, new knowledge, 
ideas, values. The news should be accessible, contain socio-humanistic valuable information that meets Ukrainian national needs. The motivation in addressing the audience is its moral-spiritual, cognitiveaesthetic interests. Knowledge of the interests of the audience and the ability to make objectively necessary information subjectively important is a significant condition for the effective impact of news on recipients.

News that professionally combine meaningful content with a set of verbal and pictorial tools will allow viewers to understand deeper and feel "Who am I?", "Who are they?", which is natural in terms of self-awareness, internal knowledge of its essence, definition of oneself in the sociocultural space.

Summing up the various interpretations of the researchers about the news, taking into account the experience of the reporters of regional TV channels and personal journalistic practice, we suppose that the TV news is a selected, organized and embodied in a certain form socially important information about facts, events, phenomena specially designed to be perceived by feelings and conscience. TV news is an audiovisual reflection of reality, which is based on a combination of words and images.

\section{REFERENCES}

1. Buhrym V. V. Zhurnalist na teleekrani : [posib. dlia stud.] / V. V. Buhrym. - K., 2000. - 46 s. 2. Braiant D. Osnovy vozdeistvyia SMY / D. Braiant, S. Tompson; [per. s anhl.]. - M.: Vyliams, 2004. 432 s. 3. Demchenko S. V. Masova komunikatsiia yak chynnyk formuvannia hromadianskoho suspilstva v nezalezhnii Ukraini (hlobalne I natsionalne): monohrafiia / S. V. Demchenko. - Dnipropetrovsk: VydvoMakovetskyi, 2009. - 368 s. 4. Dennys Э. Besedy o mas-medya / Э. Dennys, Dzh. Mэrryll; [per. s anh.]. M. : Varhyus, 1997. - 384 s. 5. Dvorianyn P. Novyny rehionalnoho telebachennia: poshuk ykreatyvnyk hrishen, dotrymannia zhurnalistskykh standartiv ta moralno-dukhovnykh tsinnostei / Paraskoviia Dvorianyn // Mediaprostir : zb. nauk. st. izsots. komunikatsii / [red. kol. : N. Poplavskatain]. - Ternopil : TNPUim. V. Hnatiuka, 2014. - S. 49-53. 6. HreskoO. V. Mizhnarodna zhurnalistyka v konteksti hlobalnykh suspilnykh transformatsii : avtoref. dys. na zdobuttia nauk. stupenia kand. filol. nauk: spets. 10.01.08 "Zhurnalistyka" / O. V. Hresko. - K., 2004. - 18 s. 7. Komova M. V. Zhanrovi osoblyvosti vykorystannia faktolohichnoho pryntsypu podannia informatsiiv ZMK / M. V. Komova // Svit sotsialnykh komunikatsii : nauk. zhurn. [hol. red. O. M. Kholod]. - T. 1. - K. : KyMU, DonNU, 2011. - S. 141-143. 8. Meleshchenko O. K. Aktualni pytannia zhurnalistyky : zb. nauk. st. $i$ vystupiv ofits. oponenta na zakhystakh doktor. $i$ kand. dys. / O. K. Meleshchenko. - K. : Palyvoda A. V., 2012. - 112 s. 9. Nedopytanskyi M. I. Telezhurnalistyka: dosvid, problemy, stratehii : [prakt. posib.] / M. I. Nedopytanskyi. K. : DP "Hazetno-zhurnalne vydavnytstvo Ministerstva kultury I turyzmu Ukrainy" , 2009. - 144 s. 10. Prokhorov E. P. Vvedenye v teoryiu zhurnalystyky : [ucheb. posobye] / E. P. Prokhorov. - M. : Yzd-vo Mosk. un-ta, 1995. - 294 s. 11. Roimann Kurt. Novyna / Kurt Roimann // Publitsystyka. Masova komunikatsiia. Media-entsyklopediia / [za zah. red. V. F. Ivanova]. - K. : Akademiia Ukrainskoi Presy, Tsentr Vilnoi Presy, 2007. - S. 239-249. 12. Samokysh I. Sohodni rol zhurnalistyky - u tomu, shchob nadavaty novynam sensu / Ihor Samokysh // Den. - 2011. - 9-10 hrud. 13. Sappak V. Televydenye y my: chetyre besedy / V. Sappak; predysl. L. P. Kravchenko ; poslesl. N. M. Zorkoi. - [3-e yzd.]. - M. : Yskusstvo, 1988. - 167 s. 14. Shults V. Novyna / Vinfrid Shults // Publitsystyka. Masova komunikatsiia. Media-entsyklopediia / [za zah. red. V. F. Ivanova]. - K. : Akademiia ukrainskoi presy, Tsentr vilnoi presy, 2007. - S. 502-537. 15. Tahhl K. Novosty v teleradyoэfyre. Podhotovka, prodiusyrovanye y prezentatsyia novostei v SMY / K. Tahhl, F. Karr, S. Khaffman ; per. s. anhl. - M. : HYTR, 2006. - 327 s. 16. Vasina O. V. Ohliad osnovnykh pidkhodiv do tlumachennia novyny yak yavyshcha mas-media [Elektronnyi resurs] I O. V. Vasina. - Rezhym dostupu : http://journlib.univ.kiev 